\title{
FORMY ADRESATYWNE \\ W PRZEKŁADZIE Z JĘZYKA ANGIELSKIEGO NA POLSKI
}

\begin{abstract}
Zarys treści: Niniejszy artykuł to próba analizy trudności - wynikających zarówno z różnic językowych, jak i kulturowych - na jakie napotyka tłumacz, przekładając formy adresatywne w tekstach angielskich na język polski. Problem ten jest stałym elementem niemal każdej interakcji, z której przekładem borykają się tłumacze. W swojej pracy pragnę przyjrzeć się bliżej repertuarowi językowemu form adresatywnych występujących w obu językach - tak zaimkom, jak i wyrażeniom rzeczownikowym - a także różnicom w użyciu tych form w obu kulturach oraz implikacjom, jakie niosą one względem przekładu.
\end{abstract}

Słowa kluczowe: tłumaczenie, formy adresatywne, problemy w tłumaczeniu

\footnotetext{
Celem niniejszego artykułu jest analiza form adresatywnych w angielskim i polskim - zarówno repertuaru językowego, jaki one tworzą, jak i różnic w ich występowaniu w obu kulturach. W dalszej części artykułu chcę przyjrzeć się problemom, z jakimi borykają się tłumacze, jeśli chodzi o formy adresatywne, oraz zaproponować pewne rozwiązania. W artykule omawiane będą zjawiska $\mathrm{W}$ ujęciu synchronicznym, a więc dotyczące współczesnego języka angielskiego i polskiego w ich standardowych odmianach.

Przez „formy adresatywne” (z ang. forms of address) rozumiem wyrażenia - zarówno pronominalne, jak i nominalne - stosowane przy zwracaniu się do rozmówców. Mowa tu o bezpośrednich zwrotach do odbiorców, w odróżnieniu od wyrażeń stosowanych do opisania osób trzecich ( $\mathrm{z}$ ang. terms of reference).
} 


\section{Wyrażenia pronominalne}

Wiele języków rozróżnia dwa rodzaje zaimków używanych przy zwracaniu się do drugiej osoby. Ten dualny podział przyjęło się nazywać podziałem na zaimki typu T i V - nazwa pochodzi od łacińskich zaimków tu (formy bardziej poufałej, występującej w liczbie pojedynczej) i vos (formy grzeczniejszej, wyrażającej większy dystans pomiędzy mówiącymi). Powyższe zróżnicowanie można także obserwować w innych językach, takich jak francuski (tu/Vous), rosyjski (ты/Bы), niemiecki (du/Sie), włoski (tu/Lei) czy grecki (esy/eseis).

Podobny podział występował w języku średnioangielskim (Middle English, ok. 1100-1500 r., zob. Wełna 1996), w którym rozróżniano liczbę pojedynczą i mnogą, oraz przypadki: mianownik i biernik:

\begin{tabular}{|l|l|l|}
\cline { 2 - 3 } \multicolumn{1}{c|}{} & L.p. & L.mn. \\
\hline Mianownik & thou & ye \\
\hline Biernik & thee & you \\
\hline
\end{tabular}

$\mathrm{Z}$ biegiem czasu podział ten uległ zanikowi, pozostawiając wyłącznie formę you we wszystkich przypadkach i bez zróżnicowania na liczbę.

Jeśli zaś idzie o zaimki składające się na repertuar polskich form adresatywnych, należy tu wymienić zaimek ty występujący w liczbie pojedynczej oraz zaimek wy w liczbie mnogiej, które można zaklasyfikować jako formę $\mathrm{T} \mathrm{w}$ przedstawionym wyżej podziale zaimków adresatywnych, gdyż stosuje się je wobec rozmówcy w relacji bardziej intymnej bądź też relacji charakteryzującej się mniejszym dystansem pomiędzy partnerami interakcji. W swoim repertuarze język polski nie ma zaimka, który można by potraktować jako klasyczny zaimek typu V, jednakże coraz więcej językoznawców (Huszcza 1996, Stone 1981) stwierdza, że należałoby za taką właśnie formę uznać rzeczowniki pan/pani/panie/panowie/państwo, które de facto pełnią funkcję zaimka drugiej osoby w bardziej oficjalnych relacjach.

Pomimo tego, że podział zaimków osobowych na $\mathrm{T}$ i $\mathrm{V}$ został powszechnie przyjęty w socjolingwistyce, wielu językoznawców słusznie twierdzi, że jest on daleki od uniwersalnego, i skupia się jedynie na językach zachodnioeuropejskich: „klasyfikacja tego typu jest więc nieprzydatna w praktyce, gdyż przypisuje ona uniwersalny charakter zjawiskom występującym w niektórych tylko językach" (Huszcza 1996: 31). Na przykład w języku rumuńskim istnieją trzy zaimki osobowe 2 os. 1.p. (tu, dumneata i dumneavoastră), w języku japońskim czy wietnamskim zupełnie nie da się oddzielić od siebie zaimków typu V i T. Wydaje się, że należałoby raczej przyjrzeć się czasownikowi oraz zjawisku honoryfikatywności (Huszcza 1996), ale jest to temat na odrębne opracowanie. 


\section{Wyrażenia nominalne}

Wyrażenia rzeczownikowe $\mathrm{w}$ zwrotach adresatywnych to przede wszystkim imiona i nazwiska, a także przezwiska, tytuły, terminy oznaczające pokrewieństwo i powinowactwo. Ponieważ angielski nie ma rozróżnienia na zaimki typu $\mathrm{T}$ i V, to właśnie formy nominalne odzwierciedlają wzajemne relacje zwracających się do siebie uczestników interakcji. W zależności od okoliczności ta sama osoba (np. John Smith) może zostać nazwana Dr Smith, John Smith, Smith, John, Johnnie, Doc, Sir czy też dad. Polskie zwroty adresatywne tworzą bogatszy repertuar ze względu na formy słowotwórcze takie jak zdrobnienia (Jan $J a s ́)$ i zgrubienia (Zbigniew - Zbych). Zwracając się do innych, Polacy mogą użyć - bardzo ostatnio popularnej - formy, będącej niejako „pomostem” pomiędzy V a T, a mianowicie konstrukcji Pan/Pani + imię, np. Pani Wando, czy ma pani zegarek? Strukturę tę traktuje się niekiedy jako formę przejściową pomiędzy byciem z kimś na pan/pani a przejściem na ty.

\section{Symetryczność relacji}

Analizując zwroty adresatywne zarówno w języku polskim, jak i angielskim, należy wspomnieć o zjawisku zwanym symetrycznością. O relacji symetrycznej mówimy wtedy, gdy partnerzy zajmują podobne miejsce w hierarchii, bądź to ze względu na pozycję zawodową, wiek czy też wykształcenie i zwracają się do siebie, używając takich samych lub podobnych form adresatywnych na zasadzie wzajemności ( $\mathrm{V} \leftrightarrow \mathrm{V}, \mathrm{T} \leftrightarrow \mathrm{T})$. Relacja asymetryczna zachodzi natomiast wtedy, gdy powyższe czynniki znacznie od siebie odbiegają, a partnerzy, zwracając się do siebie, stosują różne formy $(\mathrm{V} \leftrightarrow \mathrm{T})$.

Jako przykład relacji niesymetrycznej może posłużyć znany dialog pomiędzy białym policjantem a czarnoskórym lekarzem w 1967 r. na ulicy na południu Stanów Zjednoczonych (Ervin-Tripp 1972: 225).

What's your name, boy? the policeman asked...

Dr Poussaint. I'm a physician. ...

What's your name, boy?

Alvin' ${ }^{1}$.

Rozmowa ta niezbicie dowodzi nierównych relacji społecznych między uczestnikami - białemu wolno było zwrócić się do czarnego po imieniu, używając

- Jak ci na imię, chłopcze? - spytał policjant.

- Dr Pouissant, jestem lekarzem.

- Jak ci na imię, chłopcze?

- Alvin. 
zwrotu boy (pol. chłopcze), podczas gdy nie do pomyślenia byłaby sytuacja odwrotna. Na nierówny status społeczny i jego odzwierciedlenie w języku zwraca też uwagę Kinga Dunin w swoim artykule Nie ma miłości bez równości:

Nieważne, jaki to program telewizyjny, wszędzie jest tak samo. Jestem tu po raz pierwszy i pierwszy raz w życiu spotykam prowadzącego go redaktora. A obok siedzi sporo młodszy ode mnie, rozluźniony pan, który - sądząc po częstotliwości pojawiania się na ekranie - chyba już zamieszkał w telewizji. Panie doktorze - zwraca się do niego prowadzący, kiedy zaś przychodzi moja kolej, słyszę, oczywiście - pani Kingo. Taka poufałość ociepla relację, właściwie jest przyjemna, trudno jednak nie zauważyć, że jest w tym także protekcjonalizm, wyznaczenie miejsca. W poufały sposób zwracamy się nie tylko do tych, z którymi łączy nas jakiś rodzaj zażyłości, ale także do młodzieży, ludzi stojących niżej w hierarchii społecznej, do kobiet.

Z powyższych przykładów można wnioskować, że użycie imienia, zarówno w języku angielskim, jak i polskim, może być związane nie tylko z relacją bliskości, intymności, solidarności, lecz również może wyrażać asymetryczne relacje władzy.

\section{Różnice kulturowe w użyciu form adresatywnych}

Należy w tym miejscu zwrócić uwagę na to, że normy dotyczące zwracania się do innych różnią się w poszczególnych krajach anglojęzycznych, a także na różnice pomiędzy indywidualnymi użytkownikami języka. Trzeba też pamiętać, że język i jego użycie ulegają nieustannym zmianom - wyraźnie widać tu tendencję egalitarną, np. zwyczajem amerykańskim na uniwersytetach pojawia się tzw. ,sztuczna personalizacja” ( $\mathrm{z}$ ang. synthetic personalisation - Bargiela et al. 2002), wyrażająca się w tym, że wykładowcy i studenci coraz częściej mówią sobie po imieniu, co wcale nie musi oznaczać zażyłości. Marcjanik (2002: 394) zauważa podobną tendencję w języku polskim i nazywa ją zjawiskiem „demokratyzacji grzeczności", co przejawia się w zmniejszaniu dystansu pomiędzy uczestnikami interakcji, a w języku polskim realizuje się poprzez mówienie odbiorcy po imieniu bądź też per pan/pani + imię.

W USA mówienie komuś po imieniu nie oznacza automatycznie bycia z kimś w przyjacielskich stosunkach; jest to jedynie zwyczajowo przyjęta forma zwracania się np. do siebie między współpracownikami nawet wtedy, gdy nie darzą się zbytnią sympatią (por. Wardhaugh 1992: 267-268). Wielu Polaków błędnie sądzi, że mówienie rozmówcy po imieniu w krajach anglosaskich oznacza bycie z nim w zażyłych stosunkach, tak jak to jest w Polsce. 
W przeciwieństwie do angielskiego, w języku polskim zwrócenie się bezpośrednio do kogoś po nazwisku jest uważane za nieuprzejme (np. Pisarkowa 1979: 7). Tezie tej przeciwstawia się Miodek (1980: 178), twierdząc, że „model panie, pani + imię w wołaczu ma charakter inteligencki”, natomiast „w środowiskach nieinteligenckich, robotniczych, wiejskich przeważa zdecydowanie model panie, pani + nazwisko".

\section{Przekład form adresatywnych}

Przekład form adresatywnych powinien rozpocząc się od dokonania analizy relacji panujących pomiędzy uczestnikami interakcji przedstawionych w oryginale. Jeśli chodzi o środki niejęzykowe, należałoby tu wziąć pod uwagę kontekst wypowiedzi oraz charakterystykę osób mówiących - ich wiek, status, pozycję społeczną, wykształcenie. Natomiast w analizie językowej trzeba dokładnie przyjrzeć się zwrotom adresatywnym, a zwłaszcza wyrażeniom występującym w pozycji wołacza, np. Do you know the answer, John? vs. Do you know the answer, Mr. Brown? Pierwsze zdanie thumaczylibyśmy: Czy znasz odpowiedź, John?, a drugie: Czy zna pan odpowiedź, prosze pana?

Tłumacz powinien charakteryzować się tzw. kompetencją komunikatywną w rozumieniu Della Hymesa (1972), czyli nie tylko doskonale znać repertuar językowy, ale też wiedzieć, w jakich okolicznościach używa się poszczególnych zwrotów, zgodnie z tym, jak robią to członkowie danej społeczności.

W dalszej części artykułu przedstawię kilka przykładów zaczerpniętych z filmów anglojęzycznych wyprodukowanych w ostatnich latach, przedstawię pokrótce ich analizę i zaproponuję pewne rozwiązania translatorskie.

Rozważmy dość prosty przykład, pochodzący z filmu „Przed zachodem słońca". Scena rozgrywa się w paryskiej księgarni, gdzie w ramach promocji swojej najnowszej książki autor spotyka się z dziennikarzami, z których jeden mówi:

- Mr Wallace, the book ends on an ambiguous note. We don't know. Do you think they get back to each other in six months like they promised each other?

Adresat określany jest jako Mr Wallace, sytuacja jest dość oficjalna. Jeśli chodzi o formę adresatywną, w thumaczeniu z całą pewnością użyta zostanie forma V, czyli pan, np. Czy sądzi pan, że spotkaja się za sześć miesięcy, tak jak to sobie obiecali? Natomiast wydaje się, że błędem byłoby przekładanie zwrotu Mr Wallace na panie Wallace, ponieważ w podobnych okolicznościach nie zwrócilibyśmy się po polsku do autora po nazwisku, gdyż byłoby to stylistycznie i pragmatycznie niezręczne, a forma ta - jak pamiętamy np. $\mathrm{z}$ artykułu pro- 
fesora Miodka - nie jest używana przez środowiska inteligenckie, z jakim niewątpliwie mamy tu do czynienia.

Przyjrzyjmy się kolejnemu przykładowi. Cytat pochodzi z filmu „Notting Hill”, scena rozgrywa się w księgarni w Londynie, kiedy to sprzedawca zauważa złodzieja.

- [Sprzedawca] Excuse me?

- [Złodziej] Yes?

$-[\mathrm{S}]$ Bad news.

$-[\mathrm{Z}]$ What?

$-[\mathrm{S}]$ We've got a security camera in this bit of a shop.

$-[\mathrm{Z}]$ So?

$-[\mathrm{S}]$ So I saw you put that book down your trousers.

$-[\mathrm{Z}]$ What book?

- [S] The one down your trousers.

- [Z] I don't have a book down my trousers.

- [S] Right, I'll tell you what. I'll call the police [... $]^{2}$

$\mathrm{W}$ powyższym dialogu nie ma bezpośredniego zwrotu adresatywnego $\mathrm{z}$ użyciem wołacza - zapewne dlatego, że rozmówcy się nie znają. Kontekst wypowiedzi każe nam przypuszczać, że obaj panowie - gdyby analogiczna sytuacja zaistniała w Polsce - mówiliby sobie per pan, chyba że dzieliłaby ich spora różnica wieku (a nie jest tak w filmie), bądź też gdyby sprzedawca bardzo się zdenerwował i, chcąc podkreślić swoją pozycję, zaczął zwracać się do złodzieja per ty (tak jak to się dzieje np. przy kolizjach drogowych, kiedy to kierowcy obrzucają się wyzwiskami, np. „ty idioto, uważaj, jak jedziesz!”). Gdyby taka sytuacja zaszła w Polsce, prawdopodobnie cała rozmowa przybrałaby zdecydowanie inny charakter - bardziej burzliwy i emocjonalny, pełen oskarżeń, wyzwisk i gróźb. Jednak w kontekście tu pokazanym mamy do czynienia $\mathrm{z}$ typową angielską „flegmą" - sprzedawca jest niezwykle uprzejmy i zdystansowany. Powyższy dialog doskonale ilustruje pragmatyczne różnice między takimi sytuacjami w obu kulturach, dlatego też zapewne niektórzy thumacze pokusi-

- Przepraszam?

- Tak?

- Mam złą wiadomość.

- Jaką?

- Mamy tu w sklepiku kamerę.

- No i?

- No i widziałem, jak schował pan książkę do spodni.

- Jaką książkę?

- Tę, którą ma pan w spodniach.

- Nie mam żadnej książki w spodniach.

- No dobrze, wie pan co? Zadzwonię po policję [....] 
liby się pewnie o nazwanie go prawdziwie nieprzekładalnym. Jaką strategię powinien więc przyjąć tlumacz? Niektórzy sądzą, że w takich sytuacjach należy odejść od oryginału i zastosować strategię naturalizacji (z ang. domestication), tzn. przełożyć powyższy dialog tak, jak prawdopodobnie wyglądałby on w Polsce. Jednak takie rozwiązanie wydaje się niesłuszne z co najmniej dwóch powodów: po pierwsze, oznaczałoby to swego rodzaju zakłamanie i zaciemnianie obrazu kultury oryginału, a po drugie zdecydowanie przeczyłoby temu, co widzimy na ekranie. Pozostaje nam więc dokładne przełożenie słów bohaterów i pamiętanie o użyciu zaimka pan w takim kontekście.

Ciekawe zachowanie językowe, jeśli chodzi o formy adresatywne, można odnaleźć w filmie „Dziennik Bridget Jones”, kiedy to tytułowa bohaterka postanawia odejść z pracy i komunikuje to swemu szefowi, z którym się właśnie rozstała na gruncie prywatnym.

- [Daniel Cleaver] Bridge, c'mon, I know it's been awkward as ass, but there's no need to leave.

- [Bridget Jones] No, actually there is. I've been offered a job in television.

- [DC] Television?

- [BJ] Mmm. And they want me to start straight away. So I've got to leave in about ooh 3 minutes. So ...am.. [wychodzi z pokoju]

$-[\mathrm{DC}]$ Would you just hold it right there, Ms Jones. I am sorry to inform you that I think you'll find that by contract you are expected to give at least 6 weeks' notice.

- [BJ] Ah, yes, well... I thought with the company being in so much trouble and all, you wouldn't really miss the person who waltzes in in a see-through top and funnies about with the press releases.

- [DC] Bridget!

Na początku szef zwraca się do niej, używając zdrobnienia imienia, świadczącego o bliskości relacji (Bridge), usiłując w ten sposób załagodzić sytuację, niewątpliwie wykorzystując ich niedawną znajomość. Gdy się to nie udaje, Daniel całkowicie zmienia strategię i jednostronnie przechodzi z Bridget na pani, nazywając ją Ms Jones i zmieniając styl swojej wypowiedzi na bardzo oficjalny. Sytuacja ta powinna naturalnie znaleźć odzwierciedlenie w thumaczeniu: najpierw przy użyciu zdrobnienia i formy $\mathrm{T}$ (np. Bridge, wiem, że to strasznie niezręczna sytuacja, ale nie ma powodu, żebyś odchodzila), po czym powinno nastąpić przejście do formy V (np. Chwileczkę! Przykro mi, ale musze pania poinformować, że pani umowa o prace wymaga sześciotygodniowego okresu wypowiedzenia), na co Bridget mogłaby odpowiedzieć, zwracając się do Daniela jako do przedstawiciela pracodawcy, a więc unikając zwrotu T: No cóż, sq̨dziłam, że ze względu na trudna sytuację firma nie będzie potrzebować osoby, 
która [...] Wydaje się, że właśnie takie formy adresatywne powinny zostać użyte przez thumacza w tej sytuacji.

Problem ten doskonale ilustruje fragment autobiograficznej powieści Evy Hoffman pt. Zagubione w przekładzie, w której autorka opisuje swoje losy na emigracji w Kanadzie, dokąd wyjechała wraz z rodziną jako nastolatka. W swojej książce Hoffman (1989: 105) pokazuje życie w nowym kraju, nowej kulturze, a także swoje zmagania z nowym językiem. Poniższy fragment przedstawia pierwszy dzień w nowej szkole.

We've been brought to this school by Mr. Rosenberg, who, two days after our arrival, tells us he'll take us to classes that are provided by the government to teach English to newcomers. This morning, in the rinky-dink wooden barracks where the classes are held, we've acquired new names. All it takes is a brief conference between Mr. Rosenberg and the teacher, a kindly looking woman who tries to give us reassuring glances, but who has seen too many people come and go to get sentimental about a name. Mine - "Ewa" - is easy to change into its near equivalent in English, "Eva". My sister's name - "Alina" - poses more of a problem, but after a moment's thought, Mr. Rosenberg and the teacher decide that "Elaine" is close enough. My sister and I hang our heads wordlessly under this careless baptism. The teacher then introduces us to the class, mispronouncing our last name - "Wydra" in a way we've never heard before. We make our way to a bench at the back of the room; nothing much has happened, except a small, seismic mental shift. The twist in our names takes them a tiny distance from us - but it's a gap into which the infinite hobgoblin of abstraction enters. Our Polish names didn't refer to us; they were as surely us as our eyes or hands. These new appellations, which we ourselves can't yet pronounce, are not us. They are identification tags, disembodied signs pointing to objects that happen to be my sister and myself. We walk to our seats, into a roomful of unknown faces, with names that make us strangers to ourselves ${ }^{3}$.

\footnotetext{
${ }^{3}$ Zostałyśmy przyprowadzone do tej szkoły przez pana Rosenberga, który w dwa dni po naszym przyjeździe oświadczył nam, że zapisuje nas na organizowane przez władze kanadyjskie kursy języka dla nowo przybyłych cudzoziemców. Tego ranka, w tandetnych drewnianych barakach, w których odbywają się lekcje, otrzymałyśmy nowe imiona. Następuje to po krótkiej naradzie pana Rosenberga z nauczycielką, sympatyczną kobietą, która spogląda na nas życzliwie, chcąc nam dodać otuchy, ale która widziała za dużo uczniów przechodzących przez te drzwi, aby rozczulać się nad czyimś imieniem. Moje imię „Ewa” ławo przerobić na jego angielski ekwiwalent - „Eva”. Imię mojej siostry - „Alina” - nastręcza nieco więcej trudności, ale pan Rosenberg i nauczycielka decydują po chwili zastanowienia, że należy zmienić je na podobnie brzmiące imię „Elaine”. Podczas tego pośpiesznego chrztu obie bez słowa pochylamy głowy. Potem nauczycielka przedstawia nas klasie, błędnie wymawiając nasze nazwisko „Wydra”, a raczej nadając mu brzmienie, jakiego nigdy dotąd nie słyszałyśmy. Docieramy do ławki, która stoi w głębi klasy; nic się w zasadzie nie stało, tylko w naszej mentalności zaszła jakaś drobna sejsmiczna zmiana. Przeróbka naszych imion odsuwa je od nas na pewien dystans, ale w zaistniałą szparę wciska się nieokreślony chochlik abstrakcji. Nasze polskie imiona nie odnosiły się do nas - były po prostu częścią nas samych, podobnie jak nasze oczy czy dłonie. Te nowe określenia, których same nie potrafimy jeszcze wymówić, nie są nami. Są tabliczkami identyfikacyjnymi, pozbawionymi cielesności znakami, wskazującymi na przedmioty, którymi przypadkiem jesteśmy my - ja i moja
} 
Fragment ten doskonale ukazuje rolę imion w kształtowaniu tożsamości. Wyraźnie widać tu, że imiona nie zawsze posiadają swoje odpowiedniki w innych językach, a te, które teoretycznie można by uznać za odpowiedniki, są często zupełnie nieadekwatne, np. na poziomie ekspresywnym, bądź na poziomie skojarzeń, jakie ze sobą niosą. Dlatego też wydaje się, że często najlepszą strategią thumaczeniową w odniesieniu do nazw własnych jest zastosowanie się do rady udzielonej przez Anielę Korzeniowską i Piotra Kuhiwczaka (1998: 59), którzy odpowiadając na często zadawane pytanie, co zrobić z nazwami własnymi w thumaczeniu, odpowiadają: „ZOSTAWIĆ JE W SPOKOJU!”. Ostatni aspekt dotyczący form adresatywnych, jaki zostanie poruszony w niniejszym artykule, to przekład listów. Za przykład posłuży fragment powieści Iris Murdoch pt. A Severed Head, w którym główny bohater, Martin Lynch-Gibbon, pisze list do znajomej przepraszając za swoje zachowanie.

Dear Dr Klein,

I literally do not know how to apologise for what happened last night. What form of words can I use to say how very deeply I regret my extraordinary conduct. You will have concluded, indeed you did, if I remember, conclude that I was drunk. [...]

I am yours sincerely

Martin Lynch-Gibbon

W każdym języku listy rządzą się własnymi prawami - angielski i polski różnią się pod względem przyjętych konwencji, tj. zwrotów rozpoczynających i kończących korespondencję. Formy Dear Dr Klein nie należy zatem przekładać jako Droga Doktor Klein, gdyż jest to sprzeczne z polskim zwyczajem językowym, lecz raczej jako Szanowna Pani Doktor, jako że tam, gdzie angielski posługuje się nazwiskami, w polskim bardzo często występuje tytulatura.

\section{Wnioski}

Niniejszy artykuł miał na celu przedstawienie repertuaru językowego form adresatywnych $\mathrm{w}$ angielskim i polskim, zaprezentowanie różnic $\mathrm{w}$ użyciu tych form $\mathrm{w}$ obu kulturach oraz dyskusję, jakie implikacje translatorskie niosą ze sobą wspomniane zjawiska. Najczęstszym problemem w przekładzie form adresatywnych $\mathrm{z}$ angielskiego na polski jest błędne thumaczenie zaimka you na zaimek ty, bez względu na okoliczności towarzyszące wypowiedzi. Niemal równie

siostra. Idziemy na swoje miejsca przez klasę pełną nieznanych nam twarzy, obdarzone imionami, które czynią nas obcymi we własnych oczach (tlum. Michat Ronikier). 
często słyszy się w polskim thumaczeniu formę panie + nazwisko, która kłóci się z polską etykietą i zwyczajem językowym. Tłumacząc zwroty adresatywne, należy zatem stosować takie formy, jakich faktycznie używa się w kulturze docelowej.

Reasumując, każdy przekład powinien rozpocząć się dokładną analizą relacji pomiędzy partnerami interakcji oraz okoliczności, w jakich ona zachodzi, np. w celu ustalenia symetryczności bądź asymetryczności relacji. Następnie należałoby oddać właśnie te relacje w tłumaczeniu, nie koncentrując się na formalnej stronie zwrotów adresatywnych, lecz na pełnionej przez nie funkcji, pamiętając jednocześnie o różnicach w ich użyciu w różnych kulturach.

\section{Literatura}

Bargiela, F., Boz, C., Gokzadze, L., Hamza, A., Mills, S., Rukhadze, N. 2002, Ethnocentrism, politeness and naming strategies, [w:] Sheffield Hallam Working Papers: Linguistic Politeness in Context, http://www.shu.ac.uk/ wpw/politeness/bargiela.htm

Dunin, K. 2005, Nie ma miłości bez równości, Gazeta Wyborcza 18.01.2005, http://serwisy.gazeta.pl/wyborcza/1,34474,2499773.html

Ervin-Tripp, S. M. 1972, Sociolinguistic Rules of Address, [w:] Sociolinguistics, red. J. B. Pride, J. Holmes, Harmondsworth, s. 225-240.

Hoffman, E. 1989, Lost in Translation. A Life in a New Language, London.

Hoffman, E. 1995, Zagubione w przektadzie, przeł. M. Ronikier, London.

Huszcza, R. 1996, Honoryfikatywność: gramatyka, pragmatyka, typologia, Warszawa.

Hymes, D. 1972, On communicative competence, [w:] Sociolinguistics, red. J. B. Pride, J. Holmes, Harmondsworth.

Korzeniowska, A., Kuhiwczak, P. 1998, Successful Polish-English Translation. Tricks of the trade, Warszawa.

Marcjanik, M. 2002, Proces przewartościowania polskiej grzeczności językowej, [w:] Zbiór artykułów z konferencji „Język trzeciego tysiaclecia II”, t. I: Nowe oblicza komunikacji we współczesnej polszczyźnie, s. 391-396.

Miodek, J. 1980, Jeszcze o sposobach zwracania się do drugich, Język Polski LX 2-3, s. 177-179.

Murdoch, I. 1961, A Severed Head, Harmondsworth.

Newmark, P. 1981, Approaches to Translation, Oxford. 
Pisarkowa, K. 1979, Jak się tytutujemy i zwracamy do drugich, [w:] Język Polski LIX 1, s. 5-17.

Stone, G. 1981, Pronominal Address in Polish, International Journal of Slavic Linguistics and Poetics 23, s. 55-76.

Wardhaugh, R. 1992, An Introduction to Sociolinguistics, Oxford.

Wełna, J. 1996, A Brief Outline of the History of English, Warszawa.

\section{Filmografia}

„Dziennik Bridget Jones” (oryg. tytuł Bridget Jones's Diary) (2001), reż. Sharon Maguire, Wielka Brytania/Francja.

„Notting Hill” (oryg. tytuł Notting Hill) (1999), reż. Roger Michell, Wielka Brytania/USA.

„Przed zachodem słońca” (oryg. tytuł Before Sunset) (2004), reż. Richard Linklater, USA.

\section{Forms of address in English-Polish translation}

\section{Summary}

This article aims to analyse the difficulties - resulting both from linguistic and cultural differences - encountered by the translator when rendering English texts into Polish. The problem is not limited solely to literary texts; on the contrary, it is present in almost every interaction that is to be rendered into a target language/culture. In this paper, a linguistic repertoire of address forms will be presented, both pronouns and noun phrases, which will be then followed by a description of how these forms are employed in both cultures as well as what implications they carry for translation.

Keywords: translation, forms of address, problems in translation 